\title{
RETRACTION
}

The editors of the Brazilian Journal of Public Administration (RAP) inform that the following article failed to meet the journal's editorial guidelines and has therefore been retracted.

Preusler, T. S., Costa, P. R., Crespi, T. B., \& Cirani, C. B. S. (2020). Capacidade relacional: um estudo da Empresa Brasileira de Pesquisa Agropecuária. Revista de Administração Pública, 54(5), 1307-1333. Recuperado em https://doi.org/10.1590/0034-761220190329

Preusler, T. S., Costa, P. R., Crespi, T. B., \& Cirani, C. B. S. (2020). Relational capability: a study of the Brazilian Agricultural Research Corporation. Revista de Administração Pública, 54(5), 1307-1333. Retrieved from https://doi.org/10.1590/0034-761220190329x

Professor Alketa Peci, Ph.D.

Editor-in-chief 


\section{Relational capability: a study of the Brazilian Agricultural Research Corporation}

Taísa Scariot Preusler 1

Priscila Rezende da Costa 1

Tatiane Baseggio Crespi 1

Claudia Brito Silva Cirani 1

1 Universidade Nove de Julho / Graduate Program of Business Administration, São Paulo / SP - Brazil

The Brazilian Agricultural Research Corporation (EMBRAPA) plays an important role in Research and Development $(\mathrm{R} \& \mathrm{D})$ for generating innovations. Most innovations are generated through R\&D alliances with external partners, stimulating relational capability (RC), that is, a construct of strategic management of alliances with propositions for procedures that have not yet been empirically verified. In this context, we investigated how relational capability processes contribute to generating innovations. We conducted qualitative research using a case study based on interviews, document analysis, and observation. Three strategic R\&D alliances involving EMBRAPA and external partners constituted the analysis corpus. The main contribution to knowledge advancement is a multidimensional fraProgmework for generating innovations from strategic R\&D alliances, based on the empirical evidence of processes of EMBRAPA relational capability and its external partners. This new framework sheds light on how a public research enterprise absorbs knowledge and uncovers the processes of institutionalization and relational capability spillover. Keywords: agricultural innovation; R\&D alliances; relational capability; EMBRAPA.

\section{Capacidade relacional: um estudo da Empresa Brasileira de Pesquisa Agropecuária}

A EMBRAPA desempenha papel importante em P\&D na geração de inovações. A maioria das inovações é gerada por meio de alianças de P\&D com parceiros externos, estimulando a capacidade relacional (CR), ou seja, um construto de gerenciamento estratégico de alianças com proposições de procedimentos que ainda não foram empiricamente verificados. Nesse contexto, investigamos como os processos de capacidade relacional contribuem para gerar inovações. Para tanto, realizamos pesquisa qualitativa utilizando um estudo de caso, baseado em entrevistas, análise de documentos e observação. Três alianças estratégicas de P\&D envolvendo a EMBRAPA e parceiros externos foram analisados. A principal contribuição para o avanço do conhecimento é um framework multidimensional para gerar inovações a partir de alianças estratégicas de $\mathrm{P} \& \mathrm{D}$, com base na evidência empírica dos processos da CR da EMBRAPA e de seus parceiros externos. Este novo framework lança luz sobre como uma empresa pública de pesquisa absorve conhecimento e descobre os processos de institucionalização e repercussão da CR.

Palavras-chave: inovação agrícola; alianças de P\&D; capacidade relacional; EMBRAPA.

\section{Capacidad relacional: un estudio de la Empresa Brasileña de Investigación Agrícola}

La EMBRAPA desempeña un papel importante en Investigación y Desarrollo (I+D) para generar innovaciones. La mayoría de las innovaciones se genera a través de alianzas de I+D con socios externos, estimulando la capacidad relacional (CR), es decir, un constructo de gestión estratégica de alianzas con propuestas de procedimientos que aún no se han verificado empíricamente. En este contexto, investigamos cómo los procesos de CR contribuyen a generar innovaciones. Para ello, realizamos una investigación cualitativa utilizando un estudio de caso basado en entrevistas, análisis de documentos y observación. Tres alianzas estratégicas de I+D en las que participaron EMBRAPA y socios externos constituyeron el corpus de análisis. La principal contribución al avance del conocimiento es un framework multidimensional para generar innovaciones a partir de alianzas estratégicas de I+D, con base en la evidencia empírica de los procesos de CR de EMBRAPA y sus socios externos. Este nuevo framework arroja luz sobre cómo una empresa pública de investigación absorbe el conocimiento y descubre los procesos de institucionalización y repercusión de la CR. Palavras clave: innovación agrícola; alianzas de I+D; capacidad relacional; EMBRAPA. 


\section{INTRODUCTION}

Strategic alliances are considered a structural alternative for innovation, as they allow complementing resources, accessing new markets, and reducing production costs (De Almeida \& Costa, 2017; Dyer \& Singh, 1998). However, training for these alliances is not a simple process and the failure rate is very high. Chances of a satisfactory alliance increase if the institutions involved develop the ability to continually exchange information and knowledge with their partners (Patterson \& Ambrosini, 2015), create a governance structure for the management of alliances (Milagres, Rezende, \& Silva, 2017), and select appropriate partners, managing conflicts and establishing mutual trust (Shakeri \& Radfar, 2017). Chances of success increase if partners create protection mechanisms for assets (Costa \& Porto, 2014; Sorrentino \& Garraffo, 2010) that benefit all parties involved (Wang \& Rajagopalan, 2015).

These strategic alliance management processes integrate the Relational Capability (RC) construct (Schilke \& Goerzen, 2010), such as the results (known as relational incomes or relational benefits of economic gains) and scientific and technological results that are only achieved in an interorganizational relationship (Zhang, Li, \& Li, 2017).

In this study, $\mathrm{RC}$ is investigated from the dynamic capacity perspective, which an institution seeks through organizational routines (Helfat et al., 2009), that is, behaviors learned and repeated over time (Winter, 2003) to create, expand, or transform the resource base (Helfat et al., 2009). Its instrumenting followed the model of Schilke and Goerzen (2010), composed of a multidimensional construction, based on corporate routines and processes divided into five dimensions: interorganizational coordination, alliance transformation, learning, proactivity in alliances, and alliances portfolio. The latter was not considered, since the unit of analysis in the study is the dyad alliances, not the portfolio.

Despite RC relevance and its promising results, procedures of this construct have yet to be verified empirically:

(a) Relational capability can present differently in public research firms that form R\&D alliances with external partners, connected (when the innovation partner is driven predominantly by market demand) (Lhuillery \& Pfister, 2009) and not connected to the market (when the innovation partner is predominantly driven by research) (Appio, Martini, Petruzzelli, Neirotti, \& Van Looy, 2017);

(b) In a public research company, it is possible to systematize strategic alliance management processes (Crossan, Lane, \& White, 1999), providing opportunities for adaptation or replication of these processes in future alliances. Thus, RC can be considered "matured", that is, institutionalized (Lorenzoni \& Lipparini, 1999);

(c) In the strategic R\&D alliances of a public research company, spillovers of relational processes may occur between the partners, leading to internal improvements, or even the adoption of new R\&D practices (Walsh, Lee, \& Nagaoka, 2016).

In general, the occurrence of RC in an organization allows generating innovations, overflowing routines, processes inherent to research, and development between alliance partners. Therefore, the following question arises: How does RC contribute to the generation of agricultural innovations developed in strategic R\&D alliances, established between EMBRAPA and external partners? Thus, this study aims to bring theoretical and practical contributions in the field of RC, from the analysis of 
how this capacity contributes to the generation of agricultural innovations, developed in the strategic R\&D alliances.

These propositions require empirical evidence, given the important role that innovation plays in the agricultural sector in Brazil, and because strategic R\&D alliances have been increasingly used to generate innovations. In this study, we explore how RC processes contribute to generating innovations (Walsh et al., 2016).

We investigated from the perspective of dynamic capability (Niesten \& Jolink, 2015) how a company uses organizational routines (Helfat et al., 2009), or behaviors learned and repeated over time (Winter, 2003) to create, expand, or transform its resource base (Helfat et al., 2009), enabling it to cope with changing environments (Donada, Nogatchewsky, \& Pezet, 2015). We adopted the model of Schilke and Goerzen (2010) for research operationalization, a current model used internationally (283 citations), with the following categories of analysis: interorganizational coordination, alliance transformation, learning, proactivity in alliances and alliance portfolio. The latter was not considered, since the unit of analysis in the study is the alliance dyads, not the portfolio.

We also considered some antecedents of RC, namely experience in establishing alliances and governing alliance structures (Schilke \& Gorzen, 2010). Experience from the formation of previous strategic alliances enables organizations to develop the ability to choose potential partners to complement, manage (De Almeida \& Costa, 2017; Heimeriks \& Duysters, 2007), and make adjustments to their resources, when necessary (Heimeriks \& Duysters, 2007). Companies with an alliance structure focused on the administration of alliances can centralize information and facilitate communication between sectors (Hoang \& Rothaermel, 2005), developing the means to manage alliances more efficiently (Heimeriks \& Duysters, 2007). Concerning the alliance structure, we highlight the formalization of governance, that is, the different formalization levels of an alliance related to mechanisms for asset protection (Costa \& Porto, 2014; Sorrentino \& Garraffo, 2010), considering the partners and objects of alliances.

Regarding contribution to knowledge advancement, this study allowed the proposition of an interorganizational framework to generate innovations through strategic R\&D alliances based on the empirical evidence of processes of the Brazilian Agricultural Research Corporation (EMBRAPA) relational capability and its external partners. This new framework sheds light on how a public research company absorbs knowledge and provides unprecedented evidence of institutionalization and spillover of RC processes.

\section{THEORETICAL FRAMEWORK}

Different terms, with the same meaning, are used to define the RC construct in the literature, in addition to criticisms, such as concept latency (which makes it difficult to capture or objectively measure, for example) and the circularity risk (capacity as input, output or result). Some synonyms found in the literature are: ability to interact (Johnsen \& Ford, 2006), alliance capacity (Heimeriks \& Duysters, 2007), alliance management capacity (Niesten \& Jolink, 2015; Schilke \& Goerzen, 2010), and interorganizational collaboration (Yan et al., 2010).

Relational capacity can be developed from different ways and analyzed from different perspectives, such as dynamic capabilities (Teece, 2007), governance network (Dyer \& Singh, 1998), and network 
management (Rodriguez-Diaz \& Espino-Rodriguez, 2006). This investigated the perspective of dynamic capabilities, defined as "type of dynamic capability with the ability to create, extend, or modify the company's resource base, increased to include the resources of its alliance partners" (Helfat et al., 2009, p. 66).

The literature highlights that institutions tend to perform better when they have specialized departments, training, evaluation of codified procedures and tools, such as guidelines and contract models that aid the management of an alliance (Milagres et al., 2017). This allows centralizing, in a single place, the experience gained from different alliances, areas, and business, and developing routines to create the best capture mechanisms. This enables sharing and disseminating knowledge acquired through alliances, passing it to other company sectors, allowing its use in future alliances, promoting good performance of the alliance (Milagres et al., 2017) and companies (Kohtamäki, Rabetino, \& Möller, 2018).

The development of the alliance structure allows the creation of an adequate governance structure. In this study, we relate governance structure to the formalization level, that is, the use of governance tools, such as formal contracts, control instruments, and property clauses to prevent loss of control of property rights (Costa \& Porto, 2014; Sorrentino \& Garraffo, 2010) thus developing greater capacity to hire and develop contracts (Ariño, Reuer, Mayer, \& Jané, 2014). The greater the partner interdependence and alliance transaction risks, the more inclusive and specifically defined and designed are the contracts to prevent future opportunism (Ding, Dekker, \& Groot, 2013). Governance structure is thus relevant to RC; however, it may vary according to the alliance purpose (research or development) and the partner profile (connected and not connected to the market) (Lin \& Darnall, 2015).

Formal governance mechanisms enhance the trust and relationship level between partners and knowledge sharing (Sorrentino \& Garraffo, 2010). On the other hand, a rigid governance structure can reduce innovative $\mathrm{R} \& \mathrm{D}$ production. Thus, in this study, we expect that short- and medium-term instruments and formal contractual clauses are adopted to develop immediate solutions for the market, involving the application of protected technologies and organizations connected to the market with greater expertise in product and process development (Lhuillery \& Pfister, 2009).

In turn, in alliances established with organizations not directly connected to the market and with research expertise (public universities, public research institutes, and social organizations), long-term instruments and less formal contractual clauses are expected to be adopted, since the purpose is to advance and disseminate scientific knowledge derived from basic and/or applied research (Etzkowitz, 2017; Lhuillery \& Pfister, 2009). Therefore, we can establish the following secondary propositions: P1: Governance structure tends to be more formal when strategic alliances are established between public research institutions and organizations connected to the market; P2: Governance structure tends to be less formal when strategic alliances are established between public research institutions and organizations not connected to the market; P3: Governance structure tends to be more formal when the alliance purpose is related to short or medium term development; and P4: Governance structure tends to be less formal when the alliance purpose is related to long-term research.

A company with experience in alliances with different actors generates inventions with greater technical significance that are easier to introduce to the market (Walsh et al., 2016). This is because 
multidisciplinary collaboration allows complementation of resources and knowledge, as in the case of research institutes (scientific knowledge) and enterprises (market/industrial knowledge) (Du, Leten, \& Vanhaverbeke, 2014). Experience in alliances allows companies to access a frontier of scientific knowledge as well as alternatives to advanced scientific equipment and facilities to conduct cutting-edge research (Etzkowitz, 2017). Strategic alliances also increases the number of new products under development, growth, and diversification of the company in the long term (Kauppila, 2015).

Therefore, experience with different actors is beneficial because of greater sensitivity in the prospection of information and knowledge from multiple external sources. Consequently, we expect that various partners may be an advantage in long-term research alliances, both for the advancement of science and society as a whole. P5: Experience in establishing strategic alliances with different partners creates a potential for $R C$ when the purpose is long-term research.

On the other hand, when the formation of alliances is repeated between the same partners, knowledge is acquired on both sides and in different ways that can be captured, shared, stored, and used in future interorganizational structures with the same partners (Niesten \& Jolink, 2015). The greater the repetition of the partners in forming alliances, the more refined this relationship becomes, as patterns and routines are established, facilitating the exchange of information and expertise between partners, who can more easily determine the tasks that each one must perform (Zollo, Reuer, \& Singh, 2002).

Reoccurrence of partners leads to greater agility because it enables in-depth knowledge regarding the culture, management procedures, strengths and weaknesses, ways of acting, beliefs of the parties involved and how each partner works, facilitating the management of the alliance, strengthening trust between partners and increasing the effectiveness of alliances (Zollo et al., 2002). Reoccurrence of partners also enables drafting of detailed contracts at lower costs, since each partner has previous knowledge (Zollo et al., 2002). Therefore, replication of partners may be advantageous in alliances regarding the development of immediate solutions for the market. P6: Experience in forming strategic alliances with the same partners potentiates $R C$ when the purpose is short-and medium-term development.

Schilke and Goerzan (2010) defined RC as dimensioned from interorganizational coordination, interorganizational learning, alliance proactivity, and alliance transformation. Interorganizational coordination is composed of a set of specific mechanisms and routines that are constructed consensually between partners for the execution of tasks and investments of the alliance resources (Gulati, Lawrence, \& Puranam, 2005). Coordination plays an important role in alliances, facilitating interaction to ensure that individual alliances are managed efficiently, mainly with partners of a distinct nature, with dissimilarities related to their objectives and expectations, mitigating and solving interpretive conflicts (Estrada, Faems, Cruz, \& Santana, 2016).

Organizational learning is related to routines and mechanisms to facilitate articulation, codification, sharing and internalization of expertise of alliance partners and knowledge transfer within company boundaries (Shakeri \& Radfar, 2017). Organizational learning is also known as absorptive capacity. It is the dynamic capacity in which the company manages to create new internal resources by seeking, acquiring, assimilating, transforming, and exploring external knowledge in an innovation process (Patterson \& Ambrosini, 2015).

In the detection routine, proactivity allows organizations to identify potential opportunities and partners for the acquisition of external resources (Schilke \& Goerzen, 2010). Proactive companies 
can respond and act in a preventive way to new opportunities (Schilke \& Goerzen, 2010). Alliance transformation is related to the flexibility of partners to react to the conditions to be changed throughout the alliance (Reuer \& Zollo, 2000). Changes in contracts, governance mechanisms, and personnel are recurrent in approximately $40 \%$ of strategic alliances. Therefore, if partner institutions develop routines that modify alliances, they are able to leverage complementary resources and learn from each other in dealing with the challenges posed by conflict, unexpected spending, and moral hazard, following the alliance formation.

When companies establish organizational structures and specialized people, the strategic management processes of R\&D alliances could be institutionalized (Crossan et al., 1999), as it is expected to have achieved mature RC. P7: As companies institutionalize the processes of interorganizational coordination, their proactivity in alliances, their organizational learning and transformation of alliances, their RC becomes more mature.

Research institutes (not connected to the market) are considered important R\&D partners, since they conduct research to develop new knowledge and technologies in specific areas, contributing to innovations (Du et al., 2014; Etzkowitz, 2017). On the other hand, institutions connected to the market are intertwined with practices to market innovations (Lundvall, 1988). Thus, in R\&D alliances there is an interorganizational process spillover between companies and their partners. In other words, these actors institutionalize and subsequently transfer processes inherent to $\mathrm{R} \& \mathrm{D}$ activities, resulting in enhancement or new knowledge absorption practices. P8: In strategic R\&D alliances, processes inherent to research are spilled over from the public research company to partners (connected or not connected); and P9: In strategic R\&D alliances, processes inherent to development are forwarded from partners (connected or not connected to the market) to the public research company.

\section{METHODOLOGY}

To achieve the general objective of this research, the framework used was developed by Schilke and Goerzen (2010), whose analysis is quantitative, highlighting the need to evaluate how experience in alliance and structure of the alliance contribute to the development of RC between partners. In order to understand these factors, we used a qualitative study, because it allows approximation of subject and object: "It involves with empathy the motives, intentions, projects of actors, from which the actions, structures, and relationships become significant" (Minayo \& Sanches, 1993, p. 244). In addition, in this research type, the sample is small, allowing an in-depth study on the theme (Collis \& Hussey, 2005).

Therefore, a qualitative study was conducted through the interaction between the researcher, participants, and sites studied to clarify concepts. The environment of the studied alliances was used as data source and the researcher had a fundamental role to collect this data and selection, verification, and interpretation of information (Creswell, 2017). We used an exploratory approach through the interaction between the researcher, participants and sites studied to clarify concepts (Marconi \& Lakatos, 2006). We used a case study, since there is no dominion over the alliances in question. This allowed checking, linking, and comparing the information obtained (practical knowledge) with the study propositions (theoretical knowledge) (Godoy, 1995). 
The unit of analysis selected was EMBRAPA, since it meets the following criteria: a) recognition as one of the main actors in Brazilian agricultural research; b) experience in forming alliances for the development of agricultural innovations; and c) evidence in RC, as it promotes integration and interactions between different actors in the National System of Agricultural Research, including for-profit (companies, cooperatives, private research institutes) and non-profit organizations (public universities, public research institutes, and social organizations).

We selected three alliances to be analyzed based on the following: strategic R\&D alliances that have generated socially, economically or environmentally relevant innovations; and strategic alliances concluded in the last 15 years. This period was chosen because EMBRAPA has a history of developing plant cultivars, which takes an average of 12 years. This allowed $R \& D$ alliances on long-term research to be included to the study.

We consulted products, processes and services on EMBRAPA website (Retrieved from https://www. embrapa.br/produtos-processos-e-servicos) and technological solutions developed by the company. When filtered for the period from 2002 to 2017, the site presented 1,794 technologies. This result includes technologies generated by EMBRAPA and by EMBRAPA and its external partners. Subsequently, we consulted the cultivars registered by EMBRAPA in the National Register of Cultivars (RNC) (Retrieved from http://www. agricultura.gov.br/guia-de-servicos/registro-nacional-de-cultivares-rnc). In January 2017, EMBRAPA had approximately 1,580 cultivars registered. Finally, we consulted the website of the National Institute of Industrial Property to identify patents already registered or requested by EMBRAPA.

Considering the strategic alliances formed by EMBRAPA with external partners for the development of technologies, based on the criteria mentioned above, three R\&D alliances were selected for the study: a) Anatomical packaging for fruit, developed by EMBRAPA Agroindustry Food Unit and public research institutes (IMA and INT), innovation with environmental, economic and social benefits, resulting in 39 patents; b) Barley Cultivars - BRS Quaranta, developed by EMBRAPA Wheat Unit, Research Foundation (FAPA) and the company (AmBev), innovation that resulted in economic and social benefits. Furthermore, $90 \%$ of the breeding barley cultivars on the market were developed by EMBRAPA; and c) INOVA-Bti - insecticide, developed by EMBRAPA Genetic Resources and Biotechnology Unit, a private research institute (IMAmt) and a cooperative (Comdeagro), innovation of great social benefit, as it reduces the proliferation of Aedes aegypti mosquito, insect host of dengue, chikungunya and zika viruses.

We conducted 10 interviews: three with the heads of T\&T of the units whose innovations were selected; one with the chief of the Genetic and Biological Resources Unit (CENARGEN); and six with researchers who directly participated in R\&D activities and the coordination of selected alliances, three from EMBRAPA and three from partner institutions that were directly involved in alliances for the development of technologies at the units. Except for the interview with the FAPA researcher, which was conducted via Skype, all the others were conducted in person. We also interviewed the Coordinator of Support for Innovation and Intellectual Property of EMBRAPA by telephone to identify the characteristics related to the formation of EMBRAPA alliances and the formalization process. We also sought to understand intellectual property issues and the duration of alliances with different objectives. In the interviews, we used a semi structured script, following a model proposed by Schilke and Goezen (2010), and all the interviews were recorded, totaling six hours and 48 minutes. 
In this study, we also used observation, as it enables the researcher to identify and obtain information from the environment and from expressions, behaviors, facts, and senses of individuals during interviews in loco (Zamberlan et al., 2014). We recorded this information in a field diary.

We obtained secondary data on EMBRAPA website and its partners, by consulting the cultivars registered at RNC under EMBRAPA and collecting and confirming information on patents by searching the website of the National Institute of Industrial Property. We also analyzed documents, such as contracts, projects and folders, files, reports, minutes of meetings, regulations, newspapers and magazines. The different data sources (semi-structured interviews, documents, and non-participant observation) allowed analyzing the topics from different perspectives and comparing them to achieve consistent conclusions, a procedure known as triangulation (Zamberlan et al., 2014).

We used the content analysis technique to study the information collected from the interviews, enabling quantitative organization and classification of information in systematized categories, which, in turn, helped to reduce the amount of data collected, ensuring accurate information (Marconi et al., 2006).

The synthesis of the mooring matrix can be seen in Table 1.

\section{TABLE 1 METHODOLOGICAL MOORING MATRIX}

Nature
Approach
Method
Context of research
Unit of analysis

\section{Main questions}

In general, does the initiative for the formation of the R\&D partnership occur at your institution or your partner? Does the institution have a formal department, manuals, norms, guide, etc.? Is there a difference in the formalization of partnerships for research and partnerships for development? Does the institution adopt mechanisms to avoid opportunistic behavior, theft of information, or unilateral knowledge? Is the level of formalization of partnerships standardized or are there differences according to the object of the alliance or nature of the partner? How is each R\&D partnership coordinated? How are activities synchronized? Is it common to have requests for "procedural" or "contractual" changes in partnerships? Is it common for conflicts of interest to arise in partnerships?
Qualitative (Creswell, 2017).

Exploratory (Marconi et al., 2006).

Case study (Godoy, 1995).

EMBRAPA.

Three strategic R\&D alliances between EMBRAPA and external partners.

\begin{tabular}{ccc}
$\begin{array}{c}\text { Categories of } \\
\text { analysis and } \\
\text { propositions }\end{array}$ & $\begin{array}{c}\text { Data Collection } \\
\text { Procedures }\end{array}$ & $\begin{array}{c}\text { DataAnalysis } \\
\text { Procedures }\end{array}$ \\
\hline $\begin{array}{c}\text { Coordination and } \\
\text { Institutionalization } \\
\text { Structure of the }\end{array}$ & $\begin{array}{c}\text { Analysis (contracts } \\
\text { and projects) }\end{array}$ & $\begin{array}{c}\text { Content analysis } \\
\text { and triangulation. }\end{array}$ \\
RC (P1, P2, P3, & Non-participant \\
P4 and P 7). & observation (Field & \\
& journal). & \\
& & \\
&
\end{tabular}


Main questions
Does experience in establishing partnerships contribute to the strategic
management of partnerships for innovation? Is it common to have repeat
partnerships with the same partner?

What is the Institution's perception regarding the formation of R\&D partnerships? What knowledge, resources or assets were sought for this partnership? Can your institution learn from partners? Are there also routines and processes for transferring this knowledge? What activities did each partner develop? What is your partner's main expertise? What are the main impacts of this innovation?

\begin{tabular}{c|c|c}
$\begin{array}{c}\text { Categories of } \\
\text { analysis and } \\
\text { propositions }\end{array}$ & $\begin{array}{c}\text { Data Collection } \\
\text { Procedures }\end{array}$ & $\begin{array}{c}\text { DataAnalysis } \\
\text { Procedures }\end{array}$ \\
$\begin{array}{c}\text { Experience in } \\
\text { establishing } \\
\text { alliances (P5 and } \\
\text { P6). }\end{array}$ & $\begin{array}{c}\text { Analysis (contracts } \\
\text { and projects) } \\
\text { Non-participant } \\
\text { observation (Field } \\
\text { journal). }\end{array}$ & $\begin{array}{c}\text { Content analysis } \\
\text { and triangulation. }\end{array}$ \\
$\begin{array}{c}\text { Spillover of } \\
\text { processes } \\
\text { inherent to }\end{array}$ & $\begin{array}{c}\text { Interview Document } \\
\text { Analysis (contracts } \\
\text { research and }\end{array}$ & $\begin{array}{c}\text { Content analysis } \\
\text { and triangulation. }\end{array}$ \\
development (P8 & Non-participant \\
and P9). & observation (Field & \\
& journal). & \\
& &
\end{tabular}

Source: Research data elaborated by the authors.

\section{RESULTS}

Considering the characteristics of the alliances in question, as well as the description of the partners involved and the innovations generated, we present below a summary of the cases (Table 2).

\section{TABLE 2 INTRA-CASE SYNTHESIS OF THE RESEARCHED STRATEGIC R\&D ALLIANCES}

\begin{tabular}{|c|c|c|c|}
\hline \multirow[b]{2}{*}{ Characteristics } & \multicolumn{3}{|c|}{ Synthesized description } \\
\hline & $\begin{array}{l}\text { Alliance (1) } \\
\text { Anatomical packaging for fruits }\end{array}$ & $\begin{array}{l}\text { Alliance (2) } \\
\text { Barley cultivation - BRS } \\
\text { Quaranta }\end{array}$ & $\begin{array}{c}\text { Alliance (3) } \\
\text { INOVA-Bti - biological insecticide }\end{array}$ \\
\hline $\begin{array}{l}\text { Type of } \\
\text { innovation }\end{array}$ & Agro-industrial process. & Product (eco-innovation). & Product. \\
\hline Related topic & $\begin{array}{l}\text { Agribusiness, food security, } \\
\text { nutrition and health. }\end{array}$ & $\begin{array}{c}\text { Family agriculture, agroindustry, } \\
\text { genetic improvement and plant } \\
\text { production. }\end{array}$ & $\begin{array}{l}\text { Bio products, and similar } \\
\text { formulations. }\end{array}$ \\
\hline Release year & 2011 & 2002 & 2016 \\
\hline Conclusion year & 2015 & 2015 & 2016 \\
\hline Main applications & Transport and storage of fruits. & Winter culture. & $\begin{array}{l}\text { Reservoirs for drinking water, sites } \\
\text { suitable for proliferation or linked to } \\
\text { other means of mosquito control. }\end{array}$ \\
\hline
\end{tabular}




\begin{tabular}{|c|c|c|c|}
\hline \multirow[b]{2}{*}{ Characteristics } & \multicolumn{3}{|c|}{ Synthesized description } \\
\hline & $\begin{array}{l}\text { Alliance (1) } \\
\text { Anatomical packaging for fruits }\end{array}$ & $\begin{array}{l}\text { Alliance (2) } \\
\text { Barley cultivation - BRS } \\
\text { Quaranta }\end{array}$ & $\begin{array}{c}\text { Alliance (3) } \\
\text { INOVA-Bti - biological insecticide }\end{array}$ \\
\hline Main impacts & $\begin{array}{c}\text { Reduction of fruit losses and } \\
\text { waste; increased efficiency at } \\
\text { work; faster decomposition in } \\
\text { nature. }\end{array}$ & $\begin{array}{l}\text { Productivity increase; partial } \\
\text { or total dispensing of fungicide } \\
\text { applications. }\end{array}$ & $\begin{array}{l}\text { Control of Aedes aegypti mosquito } \\
\text { larvae, insect host of dengue, } \\
\text { chikungunya and zika viruses; does } \\
\text { not harm the environment. }\end{array}$ \\
\hline Patent deposits & 39 & 1 & Not applicable (industrial secret). \\
\hline Publications & 4 articles and 2 chapters. & 1 folder. & 1 folder. \\
\hline R\&D Activities & $\begin{array}{l}\text { Research: survey of problems } \\
\text { encountered by producers for } \\
\text { the transportation and storage } \\
\text { of fruits and vegetables; } \\
\text { selection of the most } \\
\text { suitable fiber for composite. } \\
\text { Development: add composite } \\
\text { fiber, modeling and packaging } \\
\text { design. }\end{array}$ & $\begin{array}{l}\text { Development: genetic } \\
\text { improvement of barley; } \\
\text { Research: experimentation } \\
\text { to evaluate the agronomic } \\
\text { performance of the lineages. }\end{array}$ & $\begin{array}{l}\text { Indication of strains; optimization } \\
\text { of the production process of the } \\
\text { strains; development of high-quality } \\
\text { formulations and evaluation of the } \\
\text { toxicity of products. }\end{array}$ \\
\hline Key partners & $\begin{array}{l}\text { IMA (not connected to the } \\
\text { market) and INT (not connected } \\
\text { to the market). }\end{array}$ & $\begin{array}{l}\text { AmBev (connected to the } \\
\text { market) and FAPA (not } \\
\text { connected to the market). }\end{array}$ & $\begin{array}{l}\text { IMAmt (not connected to the market) } \\
\text { and Comdeagro (connected to the } \\
\text { market). }\end{array}$ \\
\hline $\begin{array}{l}\text { Beginning of the } \\
\text { alliance }\end{array}$ & 2010 & 2002 & 2016 \\
\hline $\begin{array}{l}\text { Duration of the } \\
\text { alliance* }^{*}\end{array}$ & 5 years (medium term *). & 12 years (long term *). & 1 year (short term *). \\
\hline Formalization tool & Term of agreement. & $\begin{array}{l}\text { Technical and financial } \\
\text { cooperation agreement. }\end{array}$ & Technical Cooperation Agreement. \\
\hline $\begin{array}{l}\text { Purpose of the } \\
\text { alliance }\end{array}$ & $\begin{array}{l}\text { Development of recoverable } \\
\text { packaging for the packaging of } \\
\text { fruits and vegetables. }\end{array}$ & $\begin{array}{l}\text { Establishment of the } \\
\text { conditions for technical and } \\
\text { financial cooperation between } \\
\text { EMBRAPA, AmBev and FAPA to } \\
\text { achieve new barley cultivars. }\end{array}$ & $\begin{array}{l}\text { Development of products based on } \\
\text { Bacillus thuringiensis var. israelenses } \\
\text { and on Bacillus sphaericus, for } \\
\text { control of Simulium spp, Culex } \\
\text { quinquefasciatua, Anopheles spp and } \\
\text { Aedes aegypti. }\end{array}$ \\
\hline $\begin{array}{l}\text { Composition of the } \\
\text { financial resource }\end{array}$ & $\begin{array}{l}\text { BNDES: 7,500,217.00 BRL; } \\
\text { IMA, INT and EMBRAPA: } \\
\text { 4,179,000.00 BRL } \\
\text { (contribution). }\end{array}$ & $\begin{array}{c}\text { 4,199,195.30 BRL, with } \\
\text { 1,568,972.30 referring to the } \\
\text { participation of EMBRAPA; } \\
\text { 1,362,612.00 BRL, from } \\
\text { AmBev; and 1,267,611.00 } \\
\text { BRL, from FAPA. }\end{array}$ & $\begin{array}{l}\text { Without transfer of financial } \\
\text { resources between the institutions. } \\
\text { Values contributed: EMBRAPA } \\
\text { 120,000.00 BRL; IMAmt 60,000.00 } \\
\text { BRL; Comdeagro 60,000.00 BRL. }\end{array}$ \\
\hline
\end{tabular}




\begin{tabular}{|c|c|c|c|}
\hline \multirow[b]{2}{*}{ Characteristics } & \multicolumn{3}{|c|}{ Synthesized description } \\
\hline & $\begin{array}{l}\text { Alliance (1) } \\
\text { Anatomical packaging for fruits }\end{array}$ & $\begin{array}{c}\text { Alliance (2) } \\
\text { Barley cultivation - BRS } \\
\text { Quaranta }\end{array}$ & $\begin{array}{c}\text { Alliance (3) } \\
\text { INOVA-Bti - biological insecticide }\end{array}$ \\
\hline $\begin{array}{l}\text { The role of } \\
\text { EMBRAPA }\end{array}$ & $\begin{array}{l}\text { Surveys of the needs of each } \\
\text { product, appropriate packaging } \\
\text { characteristics. }\end{array}$ & $\begin{array}{c}\text { Crossing activities; } \\
\text { advancement of generations } \\
\text { and selection of progenies and } \\
\text { performance of evaluation and } \\
\text { value-of-crop tests and use - } \\
\text { VCU. }\end{array}$ & $\begin{array}{l}\text { Obtaining the necessary } \\
\text { authorizations to comply with the } \\
\text { legislation on access to genetic } \\
\text { patrimony; responsible for the } \\
\text { activities of the Work Plan; and } \\
\text { making available the strains to be } \\
\text { used in the contract. }\end{array}$ \\
\hline $\begin{array}{l}\text { Role of } \\
\text { partner } 1\end{array}$ & $\begin{array}{l}\text { IMA Partner: Selecting, treating } \\
\text { and characterizing agricultural } \\
\text { waste that could be used in } \\
\text { polymer composites; selecting } \\
\text { the most suitable polymer } \\
\text { materials for the preparation of } \\
\text { composites. }\end{array}$ & $\begin{array}{l}\text { Partner AmBev: Performance } \\
\text { of malt and beer quality } \\
\text { evaluation tests and validation } \\
\text { of agronomic performance of } \\
\text { cultivars registered in the name } \\
\text { of EMBRAPA. }\end{array}$ & $\begin{array}{l}\text { Partner IMAmt: Providing human } \\
\text { resources for the execution of } \\
\text { the contract, responsible for } \\
\text { paying the expenses; conducting } \\
\text { researcher hiring; making purchases } \\
\text { (consumables and equipment) and } \\
\text { contracting services. }\end{array}$ \\
\hline $\begin{array}{l}\text { Role of } \\
\text { partner } 2\end{array}$ & $\begin{array}{l}\text { Partner INT: Development of } \\
\text { primary, secondary and tertiary } \\
\text { packaging projects in the field of } \\
\text { Design. }\end{array}$ & $\begin{array}{l}\text { Partner FAPA: Performance of } \\
\text { malt and beer quality evaluation } \\
\text { tests and validation of agronomic } \\
\text { performance of cultivars registered } \\
\text { on behalf of EMBBAPA and } \\
\text { evaluation and VCU tests in strains } \\
\text { developed by EMBRAPA. }\end{array}$ & $\begin{array}{l}\text { Partner Comdeagro: Obtaining the } \\
\text { necessary authorizations to regulate } \\
\text { compliance with the legislation on access } \\
\text { to genetic patrimony and responsible } \\
\text { for the management of the process of } \\
\text { acquiring the records of the products that } \\
\text { may be obtained from the appropriate } \\
\text { authorities and producing the bio- } \\
\text { insecticide. }\end{array}$ \\
\hline
\end{tabular}

Source: Research data elaborated by the authors.

\subsection{Formalization of the governance structure of alliances}

In the alliances analyzed, in addition the nature of the actors involved, connected or not connected to the market, the formalization parameters are also determined by the strategic scope of the alliances (generation of knowledge or innovations for the market), term (short, medium or long) and nature of the activities (research or development). Table 3 shows an analysis of the adhesion of alliances to the propositions related to formalization of the governance structure, highlighting the formalization levels of partner institutions and the object of the alliance. 


\section{TABLE 3 ANALYSIS OF THE PROPOSITIONS LINKED TO THE FORMALIZATION OF THE GOVERNANCE} STRUCTURE OF ALLIANCES

\begin{tabular}{|c|c|c|c|}
\hline \multirow{2}{*}{$\begin{array}{l}\text { Propositions: } \\
\text { The formalization } \\
\text { of the governance } \\
\text { structure tends } \\
\text { to be: }\end{array}$} & \multicolumn{3}{|c|}{ Adherence to the propositions raised } \\
\hline & $\begin{array}{l}\text { Alliance } 1 \text { (A1) Anatomical } \\
\text { packaging for fruits }\end{array}$ & $\begin{array}{c}\text { Alliance } 2 \text { (A2) Barley cultivar - BRS } \\
\text { Quaranta }\end{array}$ & $\begin{array}{c}\text { Alliance } 3 \text { (A3) } \\
\text { INOVA-Bti - biological insecticide }\end{array}$ \\
\hline $\begin{array}{l}\text { (P1) ... strategic } \\
\text { alliances between } \\
\text { public research } \\
\text { institutions and } \\
\text { market-connected } \\
\text { organizations. }\end{array}$ & $\begin{array}{l}\text { NOT APPLICABLE } \\
\text { Alliance formed between public } \\
\text { research company (EMBRAPA Food } \\
\text { Agribusiness) and institutions not } \\
\text { connected to the market (IMA and } \\
\text { INT). }\end{array}$ & $\begin{array}{l}\text { ADHERENT } \\
\text { Alliance formed between public } \\
\text { research company (EMBRAPA } \\
\text { Wheat) and partner connected to } \\
\text { the market (AmBev). Certificates } \\
\text { were required for proof of } \\
\text { suitability; justification for partner } \\
\text { choice; preparation of a plan } \\
\text { with information on activities, } \\
\text { human and financial resources, } \\
\text { schedules; property and contractual } \\
\text { safeguards and royalty payments } \\
\text { clauses. }\end{array}$ & $\begin{array}{l}\text { ADHERENT } \\
\text { Alliance formed between public research } \\
\text { company (CENARGEN), a partner } \\
\text { connected to the market (Comdeagro) } \\
\text { and an unconnected partner (IMAmt). } \\
\text { The process for the formalization of the } \\
\text { alliance was evaluated by the R\&D and } \\
\text { T\&T (Transfer and Technology) sector, } \\
\text { SPAT (Technology Prospecting and } \\
\text { Evaluation Sector) and CTI (Internal } \\
\text { Technical Committee). Certificates } \\
\text { were required to prove suitability; } \\
\text { justification for partner choice; contractual } \\
\text { property and safeguard clauses; division } \\
\text { of royalty percentage. }\end{array}$ \\
\hline $\begin{array}{l}\text { (P2) ... less formal } \\
\text { when strategic } \\
\text { alliances are } \\
\text { established } \\
\text { between public } \\
\text { research } \\
\text { institutions and } \\
\text { organizations not } \\
\text { connected to the } \\
\text { market. }\end{array}$ & $\begin{array}{l}\text { NOT ADHERENT } \\
\text { An activity plan was drawn; signing } \\
\text { of confidentiality terms; property } \\
\text { and contractual safeguards and } \\
\text { royalty payments clauses. Although } \\
\text { the alliance involves partners } \\
\text { not connected to the market } \\
\text { (IMA and INT), the scope was } \\
\text { the development of packaging } \\
\text { innovations in the medium term (5 } \\
\text { years), which required formalization. }\end{array}$ & $\begin{array}{l}\text { NOT ADHERENT } \\
\text { Alliance formed between public } \\
\text { research company (EMBRAPA } \\
\text { Wheat) and partners connected to } \\
\text { the market (FAPA and AmBev). The } \\
\text { scope was barley cultivar research } \\
\text { in the long term (12 years), which } \\
\text { demanded formalization due to the } \\
\text { result of the research and partners } \\
\text { connected to the market. }\end{array}$ & $\begin{array}{l}\text { NOT ADHERENT } \\
\text { The alliance between public research } \\
\text { firm (CENARGEN) and partners not } \\
\text { connected to the market (IMAmt) for the } \\
\text { development of product innovation in the } \\
\text { short term (1 year). However, formalization } \\
\text { is required, due to the involvement of a } \\
\text { market-connected partner (Comdeagro). }\end{array}$ \\
\hline
\end{tabular}


RAP | Relational capability: a study of the Brazilian Agricultural Research Corporation

\begin{tabular}{|c|c|c|c|}
\hline & \multicolumn{3}{|c|}{ Adherence to the propositions raised } \\
\hline $\begin{array}{l}\text { of the governance } \\
\text { structure tends } \\
\text { to be: }\end{array}$ & $\begin{array}{l}\text { Alliance } 1 \text { (A1) Anatomical } \\
\text { packaging for fruits }\end{array}$ & $\begin{array}{c}\text { Alliance } 2 \text { (A2) Barley cultivar - BRS } \\
\text { Quaranta }\end{array}$ & $\begin{array}{c}\text { Alliance } 3(\mathrm{~A} 3) \\
\text { INOVA-Bti - biological insecticide }\end{array}$ \\
\hline $\begin{array}{l}\text { (P3) ... more formal } \\
\text { when the purpose } \\
\text { of the alliance is } \\
\text { related to the short } \\
\text { or medium term } \\
\text { development. }\end{array}$ & $\begin{array}{l}\text { ADHERENT } \\
\text { An activity plan was drawn; signing } \\
\text { of confidentiality terms; contractual } \\
\text { safeguard and royalty-division } \\
\text { clauses, because the scope of } \\
\text { the alliance was the development } \\
\text { of packaging innovations, in the } \\
\text { medium term ( } 5 \text { years). }\end{array}$ & $\begin{array}{l}\text { NOT APPLICABLE } \\
\text { Alliance with long-term research } \\
\text { scope (12 years), with a high } \\
\text { level of formalization, in which } \\
\text { certificates were required to prove } \\
\text { suitability; justification for partner } \\
\text { choice; preparation of a plan with } \\
\text { information on activities, human } \\
\text { and financial resources, schedules; } \\
\text { contractual property and safeguard } \\
\text { clauses. }\end{array}$ & $\begin{array}{l}\text { ADHERENT } \\
\text { The process for formalizing the alliance } \\
\text { was evaluated by the R\&D and T\&T } \\
\text { managers, SPAT and CTI. Certificates } \\
\text { were also required to prove suitability; } \\
\text { justification for partner choice; contractual } \\
\text { property and safeguard clauses; and } \\
\text { dividing royalty percentage because } \\
\text { the scope of the alliance was the } \\
\text { development of product innovations in the } \\
\text { short term of } 1 \text { year. }\end{array}$ \\
\hline $\begin{array}{l}\text { (P4) ... less formal } \\
\text { when the purpose } \\
\text { of the alliance is } \\
\text { related to long-term } \\
\text { research. }\end{array}$ & $\begin{array}{c}\text { NOT APPLICABLE } \\
\text { Formalized alliance with emphasis } \\
\text { on medium-term development } \\
\text { (5 years), with a higher level of } \\
\text { formalization. }\end{array}$ & $\begin{array}{l}\text { NOT ADHERENT } \\
\text { Alliance with purpose related to } \\
\text { long-term research, but with a high } \\
\text { level of formalization, given the } \\
\text { presence of a partner connected } \\
\text { to the market (AmBev), in which } \\
\text { certificates were required to prove } \\
\text { suitability; justification for the } \\
\text { choice of partner; preparation of a } \\
\text { plan with information on activities, } \\
\text { human and financial resources, } \\
\text { schedules; contractual property and } \\
\text { safeguard clauses. }\end{array}$ & $\begin{array}{l}\text { NOT APPLICABLE } \\
\text { Formalized alliance with emphasis on } \\
\text { short-term development (1 year), with } \\
\text { a higher level of formalization due to } \\
\text { a partner connected to the market } \\
\text { (Comdeagro). }\end{array}$ \\
\hline
\end{tabular}

Source: Research data elaborated by the authors.

\subsection{Experience in forming strategic R\&D alliances}

Table 4 presents an adherence analysis of the alliances to the propositions related to the experience of forming strategic R\&D alliances, briefly emphasizing the empowerment of RC in alliances with recidivism of partners for alliances and in long-term research alliances, when established with different partners. 


\begin{tabular}{|c|c|c|c|}
\hline Propositions: & \multicolumn{3}{|c|}{ Adherence to the propositions } \\
\hline $\begin{array}{l}\text { strategic } \\
\text { alliances when } \\
\text { the purpose is: }\end{array}$ & A1 & A2 & A3 \\
\hline $\begin{array}{c}\text { (P5) ... long- } \\
\text { term research, } \\
\text { experience in } \\
\text { establishing } \\
\text { strategic alliances, } \\
\text { with different } \\
\text { partners, enhances } \\
\text { RC. }\end{array}$ & $\begin{array}{l}\text { NOT APPLICABLE } \\
\text { Purpose of the alliance was short- } \\
\text { term development. }\end{array}$ & $\begin{array}{l}\text { ADHERENT } \\
\text { The alliance involved the } \\
\text { participation of a great diversity of } \\
\text { partners (public research company, } \\
\text { research foundation, industry, } \\
\text { cooperative and producers), whose } \\
\text { distinct knowledge allowed to } \\
\text { understand the demands of the } \\
\text { industry, market and producer; } \\
\text { expansion of the area of coverage } \\
\text { for conducting research. }\end{array}$ & $\begin{array}{l}\text { NOT APPLICABLE } \\
\text { Purpose of the alliance was short-term } \\
\text { development. }\end{array}$ \\
\hline $\begin{array}{l}\text { (P6) ... short-term } \\
\text { and medium-term } \\
\text { development, } \\
\text { experience in } \\
\text { forming strategic } \\
\text { alliances, with the } \\
\text { same partners, } \\
\text { potentiates RC. }\end{array}$ & $\begin{array}{l}\text { ADHERENT } \\
\text { Previous alliances had already been } \\
\text { formed with the partners involved } \\
\text { for other projects. Repetition } \\
\text { provides greater knowledge and } \\
\text { trust of partners and partner } \\
\text { resources, easy communication, } \\
\text { resulting in greater speed in } \\
\text { activities. }\end{array}$ & $\begin{array}{l}\text { NOT APPLICABLE } \\
\text { Purpose of the alliance is for long- } \\
\text { term research. }\end{array}$ & $\begin{array}{l}\text { ADHERENT } \\
\text { Previous partnerships had already been } \\
\text { formed with the partner; currently, there } \\
\text { are } 21 \text { alliances between EMBRAPA and } \\
\text { IMAmt; three researchers from IMAmt } \\
\text { operate within the CENARGEN. The } \\
\text { repetition sped up activities because they } \\
\text { know the people, resources, expertise, } \\
\text { limitations, issues of values and internal } \\
\text { procedures in the public research } \\
\text { company. }\end{array}$ \\
\hline
\end{tabular}

Source: Research data elaborated by the authors.

\subsection{Institutionalization of RC processes}

Based on the RC analysis, we identified in the alliances under study the presence of processes of interorganizational coordination, transformation of the alliance, learning, and proactivity (Schilke \& Goerzen, 2010). Regarding the coordination processes, we highlight the use of work plans, which described the R\&D activities of each partner, the work methodology, forecast of resources to be invested by the party, and activity schedule. These work plans were prepared from sharing prior information of resources and knowledge of each actor involved in the alliance, and the subsequent division of activities and responsibilities of each. Each actor appointed a researcher to coordinate the activities, and efforts were made to comply with these plans. 
In A1, a committee was created, composed of a researcher from each institution. The researchers coordinated the activities of their institutions and, working together, monitored the progress of $R \& D$ activities of the other institutions, ensuring synchronization of activities. For that purpose, there were monthly meetings and e-mail exchanges, and technical and financial reports were sent to the development agency every six months. Committee representatives periodically visited the research laboratories, raw material suppliers, and producers. The partner in A1 was responsible for financial control, purchase, travel authorization, and alliance accounting.

The alliance formation reviewed committees, planned meetings, assessed outcomes, and shared strategy discussions, therefore considered routines and processes that aided the coordination of the alliances. Synchronization mechanisms are necessary to reconcile the individual interests of each institution and ensure alignment of information (Gofredo \& Bataglia, 2015) and practices (Lorenzoni \& Lipparini, 1999) between the partners to ensure harmony in the pursuit of alliance objectives, resulting in efficient coordination (Gofredo \& Bataglia, 2015) and knowledge co-creation (De Silva \& Rossi, 2018).

In $\mathrm{A} 2$, routines and processes for the coordination of activities and alliance management occurred through telephone calls and constant exchange of e-mails. The partners met annually to synchronize their information. On these occasions, the activities already carried out were reported, the next activities were planned, and their respective report was drafted. Visits to the experiments were also made, with the participation of representatives of each partner institution. EMBRAPA held the responsibility to begin the renewal processes of the alliances, when the parties showed interest, and made suggestions.

In A3, an administrative manager, who assessed the progress of activities, and a manager to control the instrument validity were assigned in addition to the technical manager (researcher). Activities were synchronized through technical meetings, evaluations and reports. The researcher of the alliance partner was responsible for requesting the purchase of materials and equipment, hiring people to conduct $\mathrm{R} \& \mathrm{D}$ activities, and was accountable to the institution. There were coordination efforts through explicit actions to adjust the activities of partners to achieve the goals that were established jointly, thus, increasing relational quality, with cooperation in the alliance to the results (Estrada et al., 2016) and knowledge co-creation (De Silva \& Rossi, 2018).

EMBRAPA presented only proactivity in A1, seeking potential partners to complement its expertise. In Alliances 2 and 3, partners searched for EMBRAPA due to its scientific knowledge, experience in R\&D and resources (laboratories and genetic materials). Alliances 2 and 3 have consistently demonstrated proactivity, as they are always searching for partners who can assist in solving problems and meeting market demands. Proactivity is related to the ability to recognize the environment context by identifying the needs of customers, the target market segments or a new technological or market opportunity (Teece, 2007) and then take the initiative to seek potential partners for the acquisition of external resources (Schilke \& Goerzen, 2010).

The learning processes are related to the ability to transfer knowledge from the alliance partner to the institution (Teece, 2007). We identified an exchange of scientific and/or market knowledge between the partner institutions. In A1, EMBRAPA absorbed the specific knowledge of this partner, expertise holder in the field of polymers and then transferred this learning to other researchers and 
research teams through discussions, meetings, and technical presentations for this knowledge to be used in other EMBRAPA projects. On the other hand, IMA absorbed the technical-scientific knowledge in the post-harvest area, transmitting it to students and laboratory staff. This alliance has also resulted in patents and the publication of scientific articles and book chapters, which are means of transferring knowledge to the society.

In A2, EMBRAPA absorbed knowledge on market demands of beer and malt quality, understanding the needs and production of certain regions in Paraná State - Brazil. This knowledge was transferred to the team through seminars and lectures. The partner institution, in turn, acquired EMBRAPA technical knowledge of crops, disease control, tillage and soil conservation, and general knowledge through field days and Barley Meetings. This knowledge was transferred internally through training of technicians.

In A3, EMBRAPA acquired knowledge of product formulation and production process. Knowledge transfer occurred internally through seminars held biweekly to present the progress of projects and their results. The partner in this alliance acquired knowledge on research processes with biological microorganisms and biological control. Many of the resources sought in alliances are tacit knowledge or access to the expertise of the partner company (Dyer \& Singh, 1998). Developing learning means that an institution has the ability to acquire, assimilate, transform, and explore that knowledge, thereby, improving its performance (Zahra \& George, 2002).

We verified that changes were necessary throughout the alliances, requiring interaction and adaptation between the partners. In this sense, it is important to develop routines to aid these changes during the course of alliances (Wang \& Rajagopalan, 2015). In A1, there was a change of responsibility in the submission of patents. It was necessary to increase the quantity of molds to be developed, leading to financial adjustments and changes for the production of packages. In A2, adjustments to contractual clauses and quantitative experiments occurred at the time of contract renewal. The change in A3 was related to schedule adjustments due to a delay in the installation of equipment purchased abroad. Changes in alliances are considered natural phenomena; therefore, it is important for parties to work together to make them effective and increase the chances of satisfactory performance in alliances (Reuer \& Zollo, 2000).

The development of a capability depends on the continuous repetition of routines (Winter, 2003). Thus, when institutions establish organizational structures and hire specialists to produce favorable results, routines and management procedures of strategic $\mathrm{R} \& \mathrm{D}$ alliances are institutionalized (Crossan et al., 1999).

The analysis of three alliances showed that they all have institutionalized RC routines and processes. The institutions adopt formalized and replicable routines, processes and mechanisms for the coordination of $\mathrm{R} \& \mathrm{D}$ alliances. The institutions also demonstrated a capacity to learn from specific knowledge of their partner institutions or knowledge generated and transferred through the alliance. The institutions also proved to be flexible (in terms of transformation) with regard to changes, and there were proactive processes at EMBRAPA Food Agribusiness, FAPA and IMAmt. However, these processes did not appear to be systematized at EMBRAPA Wheat, CENARGEN and IMA, as highlighted in Table 5 (non-adherent proposition). 


\section{TABLE 5}

\section{ANALYSIS OF PROPOSITIONS LINKED TO THE INSTITUTIONALIZATION OF RC PROCESSES}

\begin{tabular}{|c|c|c|c|c|}
\hline \multirow{2}{*}{\multicolumn{2}{|c|}{$\begin{array}{l}\text { Propositions linked to the } \\
\text { institutionalization of RC } \\
\text { processes }\end{array}$}} & \multicolumn{3}{|c|}{ Adherence to propositions } \\
\hline & & A1 & A2 & A3 \\
\hline $\begin{array}{l}\text { (P7) As organizations } \\
\text { institutionalize } \\
\text { processes of } \\
\text { interorganizational } \\
\text { coordination, } \\
\text { proactivity in alliance, } \\
\text { organizational learning } \\
\text { and transformation } \\
\text { of alliances, the more } \\
\text { mature the relational } \\
\text { capability. }\end{array}$ & 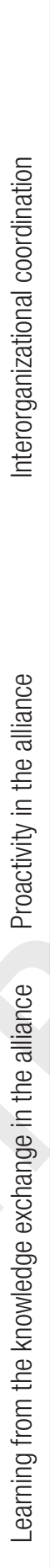 & 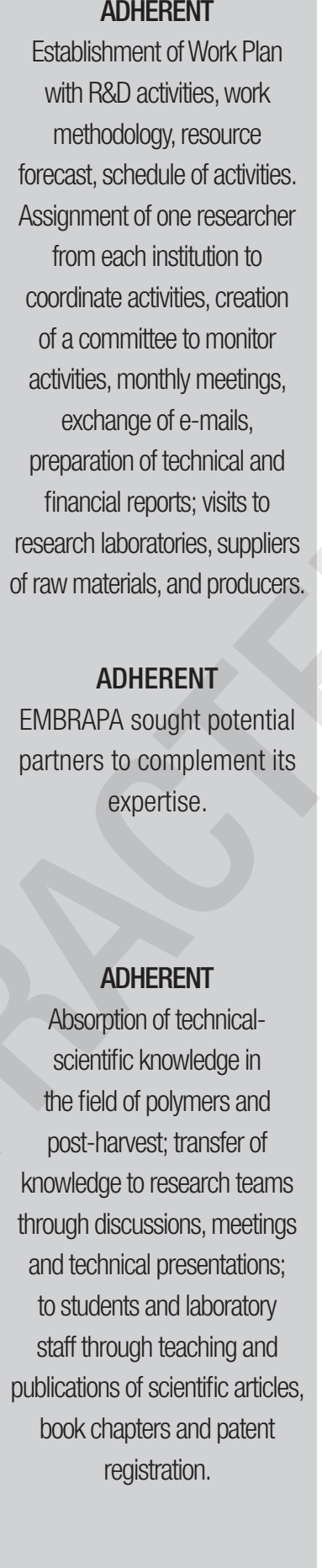 & $\begin{array}{l}\text { ADHERENT } \\
\text { Establishment of Work Plan } \\
\text { with R\&D activities, work } \\
\text { methodology, resource } \\
\text { forecast, schedule of activities. } \\
\text { Assignment of one researcher } \\
\text { from each institution to } \\
\text { coordinate activities, the } \\
\text { coordination of telephone calls, } \\
\text { exchange of e-mails, annual } \\
\text { meeting with the drafting of } \\
\text { reports and technical visits to } \\
\text { the experiments, EMBRAPA } \\
\text { employee responsible for } \\
\text { the renew process of the } \\
\text { instrument. } \\
\text { NOT ADHERENT } \\
\text { EMBRAPA was sought } \\
\text { by the partners, due to } \\
\text { its scientific knowledge, } \\
\text { experience in R\&D and } \\
\text { resources (laboratories, } \\
\text { genetic materials). } \\
\text { ADHERENT } \\
\text { Absorption of market } \\
\text { knowledge of the quality of } \\
\text { beer and malt, understanding } \\
\text { of market demands and needs, } \\
\text { acquisition of knowledge } \\
\text { of needs and production of } \\
\text { specific regions, technical } \\
\text { and scientific knowledge on } \\
\text { the development of cultivars, } \\
\text { disease control, tillage, soil } \\
\text { conservation; knowledge } \\
\text { transferred through lectures, } \\
\text { seminars, field days, training } \\
\text { and barley conferences. }\end{array}$ & $\begin{array}{l}\text { NOT ADHERENT } \\
\text { EMBRAPA was approached } \\
\text { by partners due to its scientific } \\
\text { knowledge, experience in R\&D and } \\
\text { resources (laboratories, genetic } \\
\text { materials). } \\
\text { ADHERENT } \\
\text { Absorption of formulation and } \\
\text { production knowledge, knowledge } \\
\text { related to the research processes } \\
\text { with biological microorganisms and } \\
\text { biological control, knowledge transfer } \\
\text { through seminars. }\end{array}$ \\
\hline
\end{tabular}




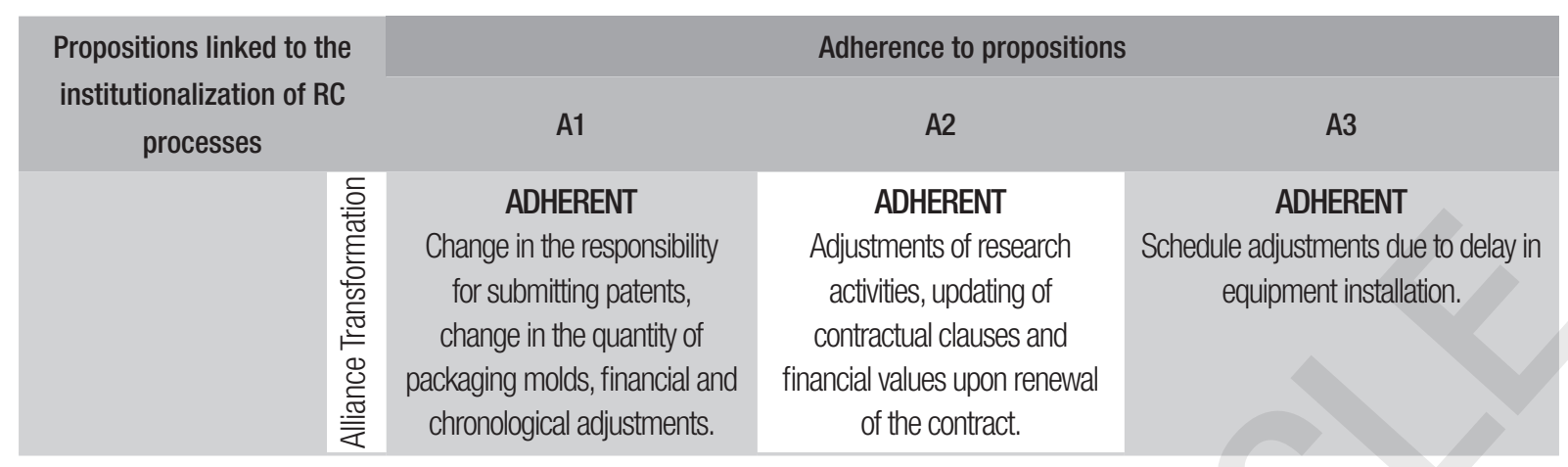

Source: Research data elaborated by the authors.

\subsection{Spillovers of relational capability}

Institutions seek competency-oriented alliances to improve their internal resources (access to complementary resources) and internal knowledge (through organizational learning and knowledge creation) (Lin \& Darnall, 2015) and are thus are more likely to search for diversified and intersectoral partners (Walsh et al., 2016).

We found in the three alliances that each partner institution had specific knowledge and resources and were motivated to form alliances to add assets, different capabilities and abilities to achieve their objectives. Both at EMBRAPA units and their partners not connected to the market (IMA and IMAmt), we identified expertise in conducting research activities, such as the partner in A1 and IMA, an institute with expertise in polymer research. On the other hand, partners connected to the market (AmBev and Comdeagro) have greater knowledge of the industry demands, since they are always seeking to develop innovations to meet demands. We found a spillover of processes from these alliances from one institution to the other and development (from partners connected or not to the market to EMBRAPA), resulting in improvements or new practices.

In A1, from the knowledge acquired from EMBRAPA Food Agribusiness, related to routines and processes inherent to post-harvest research, IMA developed a research line for packaging by establishing the process flow. In A2, based on the knowledge inherent to FAPA and market research activities by AmBev, EMBRAPA adapted an R\&D methodology for the development of barley and other cereals through the knowledge of the industry demands, such as malt quality (AmBev) and climate. At the beginning of A2 with EMBRAPA, 100\% of the barley cultivars used were derived from alliances with EMBRAPA. Today, FAPA uses 50\%, which were developed in alliances with other institutions. We also found that FAPA adapted the contractual clauses, according to the models adopted in the research conducted by EMBRAPA. Thus, we can infer that, based on this alliance, the institution began to use EMBRAPA routines and processes for R\&D.

In $A 3$, based on the difficulties encountered by the regulatory bodies for the production of this type of product, EMBRAPA developed a regulatory document of essential requirements to create alliances for the development of similar products. As the partner has expertise in formulation and production, EMBRAPA incorporated, adapted, and started to use routines and processes of formulation and production of similar products. Comdeagro, in turn, built the plant for bioinsecticide production based on knowledge, routines, and processes that were already in use in laboratories of biotechnology, due to the expertise acquired CENARGEN in biotechnology. Employees of Comdeagro attended training courses at EMBRAPA. The spillover analysis of routines and R\&D processes, according to the partner, are shown in Table 6. 


\begin{tabular}{|c|c|c|c|}
\hline \multirow{2}{*}{$\begin{array}{l}\text { Propositions linked } \\
\text { to RC spillover }\end{array}$} & \multicolumn{3}{|c|}{ Adherence to propositions } \\
\hline & $\mathrm{A} 1$ & A2 & A3 \\
\hline $\begin{array}{l}\text { (P8) In strategic } \\
\text { R \&D alliances, } \\
\text { processes inherent } \\
\text { to research are } \\
\text { spilled over from } \\
\text { the public research } \\
\text { company to the } \\
\text { partners (connected } \\
\text { or not connected). } \\
\text { (P9) In strategic } \\
\text { R \&D alliances, } \\
\text { processes inherent } \\
\text { to development are } \\
\text { spilled over from } \\
\text { partners (connected } \\
\text { or not connected) to } \\
\text { the public research } \\
\text { company. }\end{array}$ & $\begin{array}{l}\text { ADHERENT } \\
\text { Development of a research line at } \\
\text { IMA for packaging with the adoption } \\
\text { of routines and research processes } \\
\text { of EMBRAPA. }\end{array}$ & $\begin{array}{c}\text { ADHERENT } \\
\text { Adaptation at EMBRAPA of the } \\
\text { R\&D methodology for barley } \\
\text { development, resulting from } \\
\text { knowledge of industry demands } \\
\text { (AmBev) and climate and producers } \\
\text { from regions of Paraná State } \\
\text { obtained at FAPA. }\end{array}$ & $\begin{array}{l}\text { ADHERENT } \\
\text { Comdeagro built a plant for the } \\
\text { production of bioinsecticide, based on } \\
\text { research orientation and training provided } \\
\text { by EMBRAPA. }\end{array}$ \\
\hline
\end{tabular}

Source: Research data elaborated by the authors.

\section{PROPOSITIONAL INTERORGANIZATIONAL FRAMEWORK}

Based on the in-depth study of the alliances that generate agricultural innovations, we developed a propositional interorganizational framework based on a theoretical-empirical comparison, involving a public research company and its partners connected and not connected to the market. The framework is divided into six blocks, which represent empirically evidenced RC categories of analysis, including: (Block 1) Governance structure; (Block 2) Alliance experience; (Block 3) Maturity of RC; (Block 4) Spillovers of RC; (Block 5) Results; and (Block 6) Facilitator.

Block 1 represents the formalization of the governance structure, which is more formalized if one of the alliance partners is connected to the market, regardless whether the nature of the research activities is long-term or short- or medium-term development. In addition, this formalization is greater if the alliance scope is generation of innovations that may result in royalties (Figure 1).

Block 2, on the other hand, represents recidivism of partners as a potential for $\mathrm{RC}$ when the nature of the activity is developmental, as it enables greater knowledge of the partner's resources, cost accuracy of activities, and low incidence of conflicts and greater agility in achieving results. Experience with several partners, with different scientific and market knowledge, allows obtaining research results, contributing to the generation of innovation (example: "Quaranta" barley cultivar). We also found that the individual experience of researchers could improve RC of the institution, since all researchers interviewed reported having experience in forming alliances, aiding the processes of coordination, learning, proactivity, transformation, and interpersonal relations (Figure 1). 


\section{FIGURE 1 INTERORGANIZATIONAL FRAMEWORK FOR GENERATING INNOVATIONS FROM STRATEGIC R\&D ALLIANCES BASED ON THE EMPIRICAL EVIDENCE OF RC PROCESSES OF EMBRAPA AND ITS EXTERNAL PARTNERS}

BLOCK 1. Governance structure

- Formalization processes are intensified if one of the alliance partners is connected to the market, regardless of whether the research activities are for long-term or short- or medium-term development. - Formalization processes are intensified if the scope of the alliance is the generation of innovations that may result in the payment of royalties.
BLOCK 2. Alliance experience

- Partner reoccurrence processes enhance relational capacity, when the nature of the activity is development

Antecedent of $\quad$ - Processes experienced with several partners RC increase relational capacity when the nature of the activity is development

- Processes experienced individually by researchers enhance the relational capacity of the institution

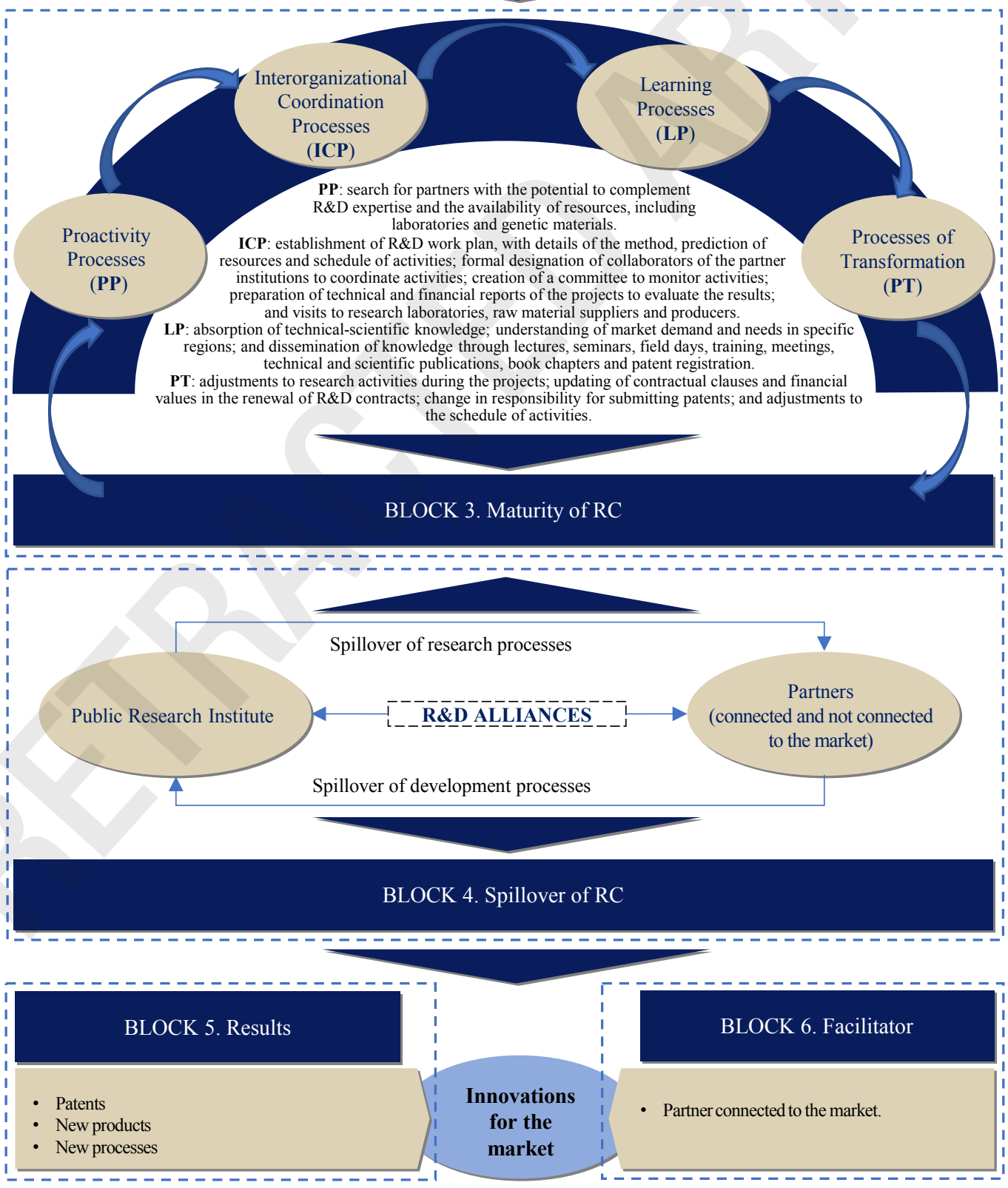

Source: Research data elaborated by the authors. 
Block 3, based on empirical evidence, shows that the more institutionalized a set of strategic management processes of $\mathrm{R} \& \mathrm{D}$ alliances in a public research company, the more institutionalized the $\mathrm{RC}$, and its constitutive processes could be replicable and adaptable in future alliances (Figure 1). We highlight a set of processes that can confer maturity to the RC:

a) Processes of interorganizational coordination: establishment of an $R \& D$ work plan, detailing the method, prediction of resources and schedule of activities; formal assignment of collaborators of the partner institutions to coordinate activities; creation of a committee to monitor activities; drafting of technical and financial reports of projects for the evaluation of results; and visits to research laboratories, suppliers of raw materials and producers;

b) Proactivity processes in the alliance: search for partners with potential to complement R\&D expertise and the availability of resources, including laboratories and genetic materials;

c) Learning: absorption of technical and scientific knowledge; understanding market demands and needs in specific regions; and dissemination of knowledge through lectures, seminars, field days, training, meetings, technical and scientific publications, book chapters and patent registration;

d) Transformation: adjusting research activities during the projects; updating contractual clauses and financial values made in the renewal of R\&D contracts; change of responsibility for submission of patents; and adjustments to activity schedule.

When an institution can develop and therefore institutionalize this set of strategic management processes of $\mathrm{R} \& \mathrm{D}$ alliances, conferring maturity to $\mathrm{RC}$, there is a spillover of research and development processes between the public research company and partners connected and not connected to the market (Figure 1).

Regarding spillover processes (Block 4), in alliances with both scopes (research and development), there is spillover from the research processes of the public research company (due to scientific expertise) to the partners (both connected and not connected to the market). On the other hand, regarding development processes, there is spillover from both partners (connected and not connected) to the public research company, resulting in the improvement of their processes or the adoption of new development practices (Figure 1). Thus, we highlighted spillover of the following R\&D processes:

a) Spillover of development processes: (1) Diversification of products and processes already existing in the public company, a reference in research after establishing an alliance with a partner aware of regional needs; (2) Adoption of new quality standards in the public enterprise, a reference in research after forming an alliance with a partner aware of industrial needs; (3) Implementation of a regulatory document of essential requirements for collaborative $\mathrm{R} \& \mathrm{D}$ in the public company after forming an alliance with a partner with greater expertise in contractual safeguards;

b) Spillover of research processes: (1) Implementation of a new research line at the partner company after the establishment of alliances with EMBRAPA, a research reference; (2) After the establishment 
of alliances with EMBRAPA, the partner incorporates knowledge that enables production of the innovative product; (3) After the alliances, employees of the partner company continued training in research at the public company.

Finally, from Blocks 5 and 6 of the propositional interdisciplinary framework, RC potentiates the development of products, processes, patents, etc. and, subsequently, innovations for the market. The framework (Figure 1) also shows that if products, processes, and patents are developed in alliances with at least one market partner, they are launched to the market more quickly, becoming innovations, as the market partners have greater expertise in commercialization or generating innovations.

\section{FINAL REMARKS}

Agricultural innovations play an important role vis-à-vis the prospects for the continued increase in population and the recurrence of climate problems. Thus, conducting $R \& D$ for the development of innovations that contribute to the increase of agricultural productivity, pest control, or climatic adaptations are valuable and crucial actions to ensure food security. In the last decades, strategic alliances have been considered an alternative to institutions, with regard to carrying out R\&D and generating innovations. Relational capacity, which has a strong relevance in this process, can directly affect the performance of strategic alliances, which leads to the need to study it further in order to use it more productively within organizations.

Thus, this study sought answers to the following question: "How does relational capacity contribute to the generation of agricultural innovations developed in strategic R\&D alliances, established between EMBRAPA and external partners?" To answer it and reach some proposals developed based on the issue, three strategic alliances, formed between EMBRAPA Units and external partners, were studied in depth.

We found that EMBRAPA and experience of its external partners in strategic R\&D alliances potentiated RC. All EMBRAPA Units and partners have experience in building alliances. The recidivism of partners has also potentiated RC in alliances, with emphasis on development, since it enables greater knowledge of resources of partners, higher accuracy of activity costs, lower incidence of conflicts, and greater agility in achieving results. In alliance with emphasis on research, experience with various partners and different knowledge potentiated RC, leading to the generation of innovation.

When institutions have and develop the dimensions and factors that empower $\mathrm{RC}$, there is a spillover of routines and processes inherent to research and development between EMBRAPA and its external partners in strategic R\&D alliances. In alliances with both scopes, research and development, there was a spillover of routines and research processes from EMBRAPA (due to scientific expertise) to the partner (connected or not to the market) and from the partner (connected or not to the market) to EMBRAPA, resulting in the improvement of routines and processes or the adoption of new practices.

EMBRAPA units and external partners have the dimensions of coordination, learning, and transformation of institutionalized RC (formalized and replicable in future alliances). Proactivity, also 
part of the RC construct, was evident at an EMBRAPA Unit (Food Agribusiness) and two partners (FAPA and IMAmt). We can consider these dimensions mature, or formalized, in these institutions and thus amenable for replication in future alliances.

Regarding the economic aspect of innovation, the anatomical packaging for fruit still has the potential to be launched and marketed. This has not yet occurred because of the absence of a marketing partner from the early stages of $R \& D$. When institutions connected to the market (companies or cooperatives) do not participate, it is more difficult for a product or process to be welcomed by the market or to reach an adequate rate of royalties in relation to the investment. In the other alliances in question (brewing barley and biological insecticide), we identified a connection with the market through the partners, such as cooperatives and enterprises, showing that innovations resulting from these alliances have already had an economic, social and environmental impact.

This study contributes to knowledge advancement on R\&D alliances in terms of experience, as previous studies had already stated the importance of accumulated experience and the reuse of partners for RC development and greater chances of success in future alliances (Kohtamäki, Rabetino, \& Möller, 2018). However, we found that the reuse of partners actually strengthens RC, when they occur in R\&D alliances on development. For R\&D alliances on research, experience with a greater diversity of partners of different natures (connected and not connected to the market) potentiates RC.

This study also contributes to the field of governance structure. The mechanisms used should be used in an appropriate way to avoid opportunistic behavior and increase the trust level between the partners; however, at the same time, the mechanisms should be used flexibly not to reduce the innovative production of $\mathrm{R} \& \mathrm{D}$ activities. This result is in agreement with the findings of recent studies (Milagres et al., 2017; Sumo, Weele, \& Duysters, 2016). On the one hand, governance structure for the alliance can improve its performance. On the other hand, it may result in greater emphasis on processes and bureaucracy, reducing the autonomy of partners, impairing the agility and customization of the alliance objectives.

Other contributions to knowledge advancement were institutionalization and spillover, culminating in a propositional framework. In R\&D alliances, when partners have developed RC, they are capable of spilling over knowledge, routines and research processes (public research institute to partner) and development (partner to public research institute), improving their processes and routines or adopting new practices. Likewise, the more institutionalized the RC routines and processes, the more mature and replicable to other alliances.

For managers of R\&D institutions, whether or not connected to the market, the study indicates that when R\&D alliances are formed, with an emphasis on the development of innovations, the recurrent partners of other alliances could potentiate RC, leading to the more agile innovation development. Conversely, when non-market institutions seek partners for R\&D alliances, for innovation development, it is important for at least one partner to be connected to the market, with potential future production capacity. Thus, managers need to play an active role in the choice of partners, according to the alliance emphasis, to achieve the goals and best possible results of the alliance. 
RAP | Relational capability: a study of the Brazilian Agricultural Research Corporation

This research is qualitative; thus, it is limited by the restricted selection of the number of cases. Consequently, it cannot be generalized to other R\&D alliances or innovation development, nor can its results be generalized in relation to other EMBRAPA units and their partners. We highlight that validity of causal inference in this type of research depends on the use and operationalization of variables, conditions or mechanisms that are general (and not specific).

We were also able to identify that, in R\&D alliances for the development of agricultural innovations, researchers of both EMBRAPA and the partners, who work directly in R\&D activities, play an important role in coordinating the activities and in interorganizational relationships. Researchers are channels through which alliances are formed, as they emerge from their network of contacts and because of their individual experience in alliances, which also contributes to their success. Thus, future studies could analyze the influence of RC of individuals on RC of the institution in strategic $\mathrm{R} \& \mathrm{D}$ alliances to generate agricultural innovations. Moreover, we suggest extending the analysis to a larger number of institutions that have formed strategic R\&D alliances in agriculture. 


\section{REFERENCES}

Appio, F. P., Martini, A., Petruzzelli, A. M., Neirotti, P., \& Van Looy, B. (2017). Search mechanisms and innovation: An analysis across multiple perspectives. Technological Forecasting \& Social Change, 120, 103-116.

Ariño, A., Reuer, J. J., Mayer, K. J., \& Jané, J. (2014). Contracts, negotiation, and learning: An examination of termination provisions. Journal of Management Studies, 51(3), 379-405.

Collis, J., \& Hussey, R. (2005). Pesquisa em Administração: um guia prático para alunos de graduação e pós-graduação. (2nd. ed). Porto Alegre, RS: Bookman.

Costa, P. R., \& Porto, G. S. (2014). Technological governance and cooperability in Brazilian multinationals. Revista de Administração de Empresas, 54(2), 201-221.

Creswell, J. (2017). Research design: Qualitative, quantitative, and mixed methods approaches. London, UK: SAGE publications.

Crossan, M. M., Lane, H. W., \& White, R. E. (1999). An organizational learning framework: From intuition to institution. Academy of management review, 24(3), 522-537.

De Almeida, J. M. S., Costa, P. R. (2017). Development of relational capability in technology-based companies in the information and communication technology sector. International Journal of Managerial Studies and Research (IJMSR), 5(4), 119-126.

De Silva, M., \& Rossi, F. (2018). The effect of firms' relational capabilities on knowledge acquisition and co-creation with universities. Technological Forecasting and Social Change, 133, 72-84.

Ding, R., Dekker, H. C., \& Groot, T. (2013). Risk, partner selection and contractual control in interfirm relationships. Management Accounting Research, 24(2), 140-155

Donada, C., Nogatchewsky, G., \& Pezet, A. (2015). Understanding the relational dynamic capabilitybuilding process. Strategic Organization, 14(2), 93-117.

Du, J., Leten, B., \& Vanhaverbeke, W. (2014). Managing open innovation projects with science- based and market-based partners. Research Policy, 43(5), 828-840.

Dyer, J. H., \& Singh, H. (1998). The relational view: Cooperative strategy and sources of interorganizational competitive advantage. Academy of management review, 23(4), 660-679.

Estrada, I., Faems, D., Cruz, N. M., \& Santana, P. P. (2016). The role of interpartner dissimilarities in Industry-University alliances: Insights from a comparative case study. Research Policy, 45(10), 2008-2022.

Etzkowitz, H. (2017). Innovation Lodestar: The entrepreneurial university in a stellar knowledge firmament. Technological Forecasting and Social Change, 123, 122-129.

Godoy, A. S. (1995). Pesquisa qualitativa: tipos fundamentais. Revista de Administração de Empresas, 35(3), 20-29.

Gofredo, T. R., \& Bataglia, W. (2015). Os mecanismos de sincronização em alianças estratégicas. Revista de Administração da Universidade Federal de Santa Maria, 8(4), 633-649.

Gulati, R., Lawrence, P. R., \& Puranam, P. (2005). Adaptation in vertical relationships: Beyond incentive conflict. Strategic Management Journal, 26(5), 415-440.

Heimeriks, K. H., \& Duysters, G. (2007). Alliance capability as a mediator between experience and alliance performance: an empirical investigation into the alliance capability development process. Journal of Management Studies, 44(1), 25-49.

Helfat, C. E., Finkelstein, S., Mitchell, W., Peteraf, M., Singh, H., Teece, D., ... Winter, S. G. (2009). Dynamic capabilities: Understanding strategic change in organizations. Oxford, UK: Blackwell.

Hoang, H., \& Rothaermel, F. T. (2005). The effect of general and partner-specific alliance experience on joint R\&D project performance. Academy of Management Journal, 48(2), 332-345.

Johnsen, R. E., \& Ford, D. (2006). Interaction capability development of smaller suppliers in relationships with larger customers. Industrial Marketing Management, 35(8), 1002-1015.

Kauppila, O. P. (2015). Alliance management capability and firm performance: Using resource- 
based theory to look inside the process black box. Long Range Planning, 48(3), 151-167.

Kohtamäki, M., Rabetino, R., \& Möller, K. (2018). Alliance capabilities: A systematic review and future research directions. Industrial Marketing Management, 68, 188-201.

Lhuillery, S., \& Pfister, E. (2009). R\&D cooperation and failures in innovation projects: Empirical evidence from French CIS data. Research Policy, 38(1), 45-57.

Lin, H., \& Darnall, N. (2015). Strategic alliance formation and structural configuration. Journal of Business Ethics, 127(3), 549-564.

Lorenzoni, G., \& Lipparini, A. (1999). The leveraging of interfirm relationships as a distinctive organizational capability: a longitudinal study. Strategic Management Journal, 20(4), 317-338.

Lundvall, B. A. (1988). Innovation as an interactive process: From user-producer interaction to the National System of Innovation. In G. Dosi, C. Freeman, R. Nelson, G. Silverberg \& L. Soete. (Eds.), Technical change and economic theory (Chap. 11, pp. 349-369). London, UK: Pinter Publishers.

Marconi, M. de A., \& Lakatos, E. M. (2006). Técnicas de pesquisa (6. ed, Vol. 4). São Paulo, SP: Atlas.

Milagres, R., Rezende, O., \& Silva, S. A. G. D. (2017). Papel e posição do departamento de alianças: caso EMBRAPA. Revista de Administração Pública, 51(3), $431-450$.

Minayo, M. de S., \& Sanches, O. (1993). Quantitativoqualitativo: oposição ou complementaridade. Cadernos de saúde pública, 9(3), 239-262.

Niesten, E., \& Jolink, A. (2015). The impact of alliance management capabilities on alliance attributes and performance: a literature review. International Journal of Management Reviews, 17(1), 69-100.

Patterson, W., \& Ambrosini, V. (2015). Configuring absorptive capacity as a key process for research intensive firms. Technovation, 36, 77-89.

Reuer, J., \& Zollo, M. (2000). Managing governance adaptations in strategic alliances. European Management Journal, 18(2), 164-172.

Rodríguez-Díaz, M., \& Espino-Rodríguez, T. F. (2006). Redesigning the supply chain: reengineering, outsourcing, and relational capabilities. Business Process Management Journal, 12(4), 483-502.

Shakeri, R., \& Radfar, R. (2017). Antecedents of strategic alliances performance in biopharmaceutical industry: A comprehensive model. Technological Forecasting and Social Change, 122, 289-302.

Schilke, O., \& Goerzen, A. (2010). Alliance management capability: an investigation of the construct and its measurement. Journal of Management, 36(5), 1192-1219.

Sorrentino, F., \& Garraffo, F. (2012). Explaining performing $\mathrm{R} \& \mathrm{D}$ through alliances: Implications for the business model of Italian dedicated biotech firms. Journal of Management \& Governance, 16(3), 449-475.

Sumo, R., Valk, W., Weele, A., \& Duysters, G. (2016). How Incomplete Contracts Foster Innovation in Inter-Organizational Relationships. European Management Review, 13(3), 179-192.

Teece, D. J. (2007). Explicating dynamic capabilities: the nature and microfoundations of (sustainable) enterprise performance. Strategic Management Journal, 28(13), 1319-1350.

Walsh, J. P., Lee, Y.-N., \& Nagaoka, S. (2016). Openness and innovation in the US: Collaboration form, idea generation and implementation. Research Policy, 45(8), 1660-1671.

Wang, Y., \& Rajagopalan, N. (2015). Alliance capabilities review and research agenda. Journal of Management, 41(1), 236-260.

Winter, S. G. (2003). Understanding dynamic capabilities. Strategic Management Journal, 24(10), 991-995.

Zamberlan, L., Rasia, P. C., Souza, J. D. S., Grison, A. J., Gagliardi, A. O., Teixeira, E. B., ... Allebrandt, S. L. (2014). Pesquisa em ciências sociais aplicadas. Ijuí, RS: Editora Unijuí.

Zhang, S., Li, N., \& Li, J. (2017). Redefining relational rent. Technological Forecasting and Social Change, $117,315-326$.

Zollo, M., Reuer, J. J., \& Singh, H. (2002). Interorganizational routines and performance in strategic alliances. Organization Science, 13(6), $701-713$. 


\section{Taísa Scariot Preusler}

iD

https://orcid.org/0000-0002-0136-9040

Master in Business Administration at Universidade Nove de Julho (UNINOVE).E-mail: taisa.s@hotmail.com

\section{Priscila Rezende da Costa}

https://orcid.org/0000-0002-7012-0679

Ph.D. in Business Administration; Full Professor in Graduate Program of Business Administration at Universidade Nove de Julho (UNINOVE). E-mail: priscilarezende@yahoo.com.br

\section{Tatiane Baseggio Crespi}

iD

https://orcid.org/0000-0001-9740-8069

Master in Business Administration at Universidade Nove de Julho (UNINOVE).

E-mail: tatianebaseggiocrespi@gmail.com

\section{Claudia Brito Silva Cirani}

https://orcid.org/0000-0002-7245-3178

Ph.D. in Economic; Full Professor in Graduate Program of Business Administration at Universidade Nove de Julho (UNINOVE).E-mail: claudiabscirani@gmail.com 